\title{
Implementasi Prinsip Pembuktian Terbalik Dalam Penyelesaian Sengketa Konsumen Di BPSK
}

\author{
Shera Aulia Simatupang \\ Faculty of Law, Padjadjaran University, Bandung, Indonesia \\ sheraaulias@gmail.com
}

Submitted: 2017-09-07; Reviewed: 2017-10-10; Accepted: 2017-11-27

\begin{abstract}
Article 28 Consumer Protection Act (CPA) regulates the reversal burden of proof that imposing the proof of fault to businesses. However, it is not sufficiently clear and decisive set in CPA, so the implementation still poses various problems. The legal issues examined in this research are about the process of sharing the burden of proof in consumer disputes settlement at BPSK and juridical implications of a BPSK decision that is not in accordance with the process of proof that has been regulated in CPA. The results obtained from this study show that the reversal burden of proof principle can not be applied literally without seeing the case being handled. Implementation of reversal burden of proof principle should still consider the general principle of proof in Article 1865 of the The Code of Civil Law. This provision authorizes BPSK Assembly to order one party to prove on matters presented by referring to the reversal burden of proof principle. In addition, the exceptions in Article 19 Paragraph (5) and Article 27 of CPA should still be considered. BPSK decision can be accepted and implemented or can be denied due process of evidence is not in accordance with the regulation. Discordance procedures of the process of proof creates legal implication in the form of BPSK decision cancellation which can only be reached through the legal remedy of objection and appeal as provided in Article 56 Paragraph (2) and Article 58 Paragraph (2)CPA.
\end{abstract}

Keywords: Reversal burden of proof; Consumer Dispute; BPSK

\section{PENDAHULUAN}

Dalam upaya memberikan perlindungan hukum bagi konsumen, pemerintah Indonesia mengeluarkan Undang-Undang Nomor 8 Tahun 1999 Tentang Perlindungan Konsumen dalam Lembaran Negara Republik Indonesia Tahun 1999 Nomor 42, Tambahan Lembaran Negara
Republik Indonesia Nomor 3821 (UUPK). Salah satu pertimbangan pembentukan UUPK yang dicantumkan dalam konsideran huruf $\mathrm{f}$ adalah untuk mewujudkan keseimbangan kepentingan antara konsumen dan pelaku usaha sehingga tercipta perekonomian yang sehat, mengingat selama ini disinyalir 
adanya kedudukan yang tidak seimbang antara pelaku usaha dan konsumen.

Keseimbangan kedudukan antara konsumen dan pelaku usaha harus tetap dipertahankan, terutama saat terjadi benturan kepentingan antara konsumen dan pelaku usaha yang dapat menimbulkan suatu sengketa yang disebut dengan sengketa konsumen. Dalam Pasal 1 Angka 8 Keputusan Menteri Perindustrian Dan Perdagangan No. 350/MPP/Kep/12/2001 Tentang Pelaksanaan Tugas Dan Wewenang BPSK dinyatakan bahwa sengketa konsumen adalah sengketa antara pelaku usaha dengan konsumen yang menuntut ganti rugi atas kerusakan, pencemaran atau kerugian lain yang diderita konsumen akibat mengkonsumsi barang dan atau memanfaatkan jasa dari pelaku usaha. Menurut Pasal 45 ayat (1) UUPK, penyelesaian sengketa konsumen dapat ditempuh melalui 2 (dua) cara, yaitu dengan menggugat pelaku usaha melalui BPSK maupun di pengadilan. Dalam proses penyelesaian sengketa ini, pembuktian menjadi bagian penting karena suatu putusan yang dijatuhkan hakim sangat bergantung pada pembuktian yang dihadapkan padanya.

Suatu pembuktian dilakukan untuk memperoleh kebenaran ${ }^{1}$ dari peristiwa atau hak yang dalam hukum acara perdata dikenal sebagai asas umum pembuktian sebagaimana dimaksud Pasal 1865 KUHPerdata/163 HIR, yaitu bahwa penggugat maupun tergugat diberikan

\footnotetext{
${ }^{1}$ Sudikno Mertokusumo, Hukum Acara Perdata Indonesia, Edisi Ke-delapan, Yogyakarta: Liberty Yogyakarta, 2009, hlm. 133-134

2 Achmad Ali dan Wiwie Heryani, Asas-Asas Hukum Pembuktian Perdata, Jakarta: Kencana, 2012, hlm. 135

3 Subekti, Hukum Pembuktian, Jakarta: Pradnya Paramita, 1983, hlm. 20
}

beban pembuktian. Jika salah satu pihak tidak dapat membuktikan peristiwa/hak yang menjadi beban pembuktiannya, maka pihak tersebut harus menanggung risiko pembuktia $^{2}$. Secara sederhana, pembuktian pada proses peradilan perdata mensyaratkan pihak yang menuntut suatu hak harus membuktikan hak yang dituntutnya ${ }^{3}$. Jika ini diterapkan dalam proses pembuktian sengketa konsumen, maka baik konsumen maupun pelaku usaha dapat dibebani pembuktian. Konsekuensinya, jika mengacu pada Pasal 1365 KUHperdata, konsumen wajib pula membuktikan adanya kesalahan pelaku usaha ${ }^{4}$. Hal ini sulit dilakukan mengingat selain secara sosial ekonomi konsumen berkedudukan lebih lemah, peristiwaperistiwa negatif seperti unsur kesalahan pelaku usaha dalam proses produksi, pendistribusian dan penjualan barang memang lebih sulit dibuktikan ${ }^{5}$.

UUPK dalam Pasal 28 mengatur mengenai beban pembuktian khusus dalam penyelesaian sengketa konsumen menyatakan bahwa pembuktian terhadap ada tidaknya unsur kesalahan dalam gugatan ganti rugi sebagaimana dimaksud dalam Pasal 19, Pasal 22, dan Pasal 23 merupakan beban dan tanggungjawab pelaku usaha. Pembuktian ini disebut beban pembuktian terbalik yang dilakukan dengan membebankan pelaku usaha pembuktian atas ada tidaknya unsur kesalahan, sedangkan konsumen dibebani pembuktian atas kerugian yang diderita

4 Ahmadi Miru \& Sutarman Yodo, Hukum Perlidungan Konsumen, Jakarta: Raja Grafindo Persada, 2004, hlm. 168

5 Liya Sukma, "Pertanggung Jawaban Produk (Product Liability) Sebagai Salah Satu Alternatif Perlindungan Konsumen", Dialogia Iuridica, Volume 7 Nomor 2, 2016, hlm. 35 
konsumen akibat mengkonsumsi barang dan atau jasa dari pelaku usaha ${ }^{6}$. Pasal 28 UUPK ini merupakan ketentuan beban pembuktian bersifat khusus dari ketentuan umum dalam Pasal 1865 KUHPerdata/163 HIR. Pada prinsip pembuktian terbalik, pelaku usaha harus membuktikan bahwa ia tidak bersalah. Jika tidak dapat membuktikan hal tersebut, maka dengan sendirinya pelaku usaha dianggap bersalah dan diwajibkan memberikan ganti kerugian kepada konsumen.

BPSK sebagai alternatif penyelesaian sengketa konsumen diluar pengadilan memberikan pilihan bagi konsumen perorangan ${ }^{7}$ maupun pelaku usaha untuk menyelesaikan sengketa yang sedang dihadapi. BPSK merupakan lembaga nonstruktural ${ }^{8}$, namun putusan yang dikeluarkan oleh BPSK adalah final dan mengikat, sehingga memiliki kekuatan hukum yang sama bagi para pihak yang bersengketa untuk dilaksanakan. Putusan tersebut memberi shock therapy bagi pelaku usaha karena dapat dijadikan bukti permulaan ${ }^{9}$. Jika salah satu pihak tidak puas terhadap putusan BPSK, maka pihak tersebut dapat mengajukan upaya hukum berupa pengajuan keberatan berdasarkan alasan-alasan yang disebutkan perundangundangan, termasuk jika putusan tersebut didasarkan atas pertimbangan Majelis BPSK yang tidak sesuai dengan prinsip pembuktian terbalik sebagaimana diatur dalam Pasal 28 UUPK $^{10}$.

6 Susanti Adinugroho, Proses Penyelesaian Sengketa Konsumen Ditinjau Dari Hukum Acara Serta Kendala dan Implementasinya, Jakarta: Prenada Media Group, 2008, hlm. 184-185

7 Gunawan Widjaja dan Ahmad Yani, Hukum Tentang Perlindungan Konsumen, Jakarta: Gramedia Pustaka Utama, 2003, hlm. 78

8 B. Rini Heryanti dan Dewi Tuti Muryati, "Pelaksanaan Tugas Dan Wewenang Badan
Pada kasus gugatan Ludmilla Arif kepada PT Nissan Motor Indonesia (PT NMI), Ludmilla (konsumen) menggugat PT NMI ke BPSK DKI Jakarta karena merasa dirugikan atas pemberitahuan/iklan Mobil Nissan March. Penggugat mengajukan bukti-bukti berupa 3 buah iklan/surat kabar yang memuat pemberitaan bahwa produk Nissan March merupakan mobil yang hemat bahan bakar dengan pemakaian dalam kota adalah 18,5 $\mathrm{km} /$ liter. Menanggapi gugatan konsumen, pelaku usaha melakukan test drive terhadap mobil konsumen dan berhasil membuktikan bahwa mobil milik penggugat telah sesuai dengan pemberitaan/iklan, namun dirasa belum cukup oleh Majelis BPSK karena dianggap tidak independen. Iklan/surat kabar yang diajukan konsumen tersebut kemudian menjadi bahan pertimbangan majelis BPSK dalam pengambilan keputusan.

Dalam putusan BPSK DKI Jakarta No. 099/Pts.A/BPSK-DKI/II/2012 tanggal 16 Februari 2012, gugatan dimenangkan oleh konsumen yang kemudian dikuatkan dalam upaya hukum keberatan di Pengadilan Negeri Jakarta Selatan hingga pada tingkat kasasi di Mahkamah Agung. Dalam kasus ini pembuktian kesalahan pelaku usaha tidak dilaksanakan oleh pelaku usaha melainkan oleh konsumen. Proses ini menunjukkan adanya ketidaksesuaian antara proses pembuktian di BPSK dengan prinsip pembuktian terbalik sebagaimana

Penyelesaian Sengketa Konsumen (BPSK) Kota Semarang Dalam Penyelesaian Sengketa Konsumen Berdasarkan Undang-Undang No.8 Tahun 1999 Tentang Perlindungan Konsumen", J. Dinamika Sosbud, Volume 13 Nomor 2, 2011, hlm. 7

${ }^{9}$ Gunawan Widjaja dan Ahmad Yani, Op. Cit., hlm. 73

${ }^{10}$ Susanti Adi Nugroho, Op. Cit., hlm. 185 
yang telah diamanatkan dalam Pasal 28 UUPK.

Melalui penelitian ini diharapkan dapat diketahui bagaimana sebenarnya implementasi prinsip pembuktian terbalik dalam penyelesaian sengketa di BPSK dan bagaimana implikasi yuridis suatu putusan BPSK yang diputuskan tidak sesuai dengan proses pembuktian yang diatur dalam UUPK.

\section{PEMBAHASAN}

\section{Pembagian Beban Pembuktian dalam} Proses Penyelesaian Sengketa Konsumen di BPSK Dikaitkan dengan Prinsip Pembuktian Terbalik

Konsumen yang dirugikan dapat menuntut ganti kerugian pada pelaku usaha. Ganti kerugian merupakan hak konsumen jika barang dan/atau jasa yang diterimanya tidak sesuai dengan perjanjian atau tidak sebagaimana mestinya.

Gugatan ganti kerugian dapat diajukan konsumen ke pengadilan atau melalui BPSK berdasarkan wanprestasi atau perbuatan melawan hukum yang dilakukan oleh pelaku usaha. Gugatan wanprestasi mengharuskan adanya suatu perjanjian yang sebelumnya telah dibuat antara pelaku usaha dan konsumen dan perjanjian tersebut telah dilanggar oleh pelaku usaha. Jika gugatan ganti kerugian didasarkan pada perbuatan melawan hukum, maka terdapat beberapa hal yang harus diperhatikan sesuai dengan ketentuan Pasal 1365 KUHPerdata, yaitu:
a. Perbuatan yang melawan hukum
b. Terdapat kerugian
c. Terdapat kesalahan

\footnotetext{
${ }^{11}$ Buku Pedoman Operasional ke-2 (dua) Badan Penyelesaian Sengketa Konsumen Provinsi DKI Jakarta, hlm. 19
}

d. Adanya hubungan kausal antara kerugian konsumen dengan perbuatan melawan hukum.

Penyelesaian sengketa konsumen melalui BPSK diawali dengan mengajukan tuntutan atau pengaduan oleh konsumen itu sendiri maupun ahli warisnya, baik secara tertulis maupun lisan melalui Sekretariat BPSK $^{11}$. Konsumen yang dimaksud adalah konsumen akhir, yaitu setiap orang yang membutuhkan barang dan jasa untuk mempertahankan hidupnya sendiri, keluarganya, ataupun untuk memelihara / merawat harta bendanya tanpa dimaksudkan untuk diperdagangkan kembali. Mengenai tata cara pengajuan tuntutan ke BPSK tidak diatur oleh BPSK, oleh karena itu tata cara pengajuan gugatan atau tuntutan melalui BPSK mengikuti kebiasaan umum yang berlaku dalam perkara perdata ${ }^{12}$.

Pembuktian merupakan salah satu tahap yang sangat penting dalam proses penyelesaian sengketa. Berdasarkan asas umum pembuktian pada Pasal 1865 KUHPerdata / 163 HIR, baik penggugat maupun tergugat diberikan hak untuk membuktikan dalil-dalilnya. Berdasarkan pasal ini pula seorang hakim dapat membebankan pembuktian kepada salah satu pihak. Pasal 1865 KUHPerdata / 163 HIR menyatakan bahwa siapa yang berhak dialah yang membuktikan. Ini berarti bahwa keduabelah pihak, baik penggugat maupun tergugat dapat dibebani pembuktian, yaitu penggugat membuktikan peristiwa yang diajukannya, sedangkan tergugat mengajukan bantahannya.

12 Janus Sidabalok, Hukum Perlindungan Konsumen Di Indonesia, Cetakan Ke III, Bandung: Citra Aditya Bakti, 2014, hlm. 132 
Penilaian pembuktian yang diajukan masing-masing pihak diserahkan kepada hakim sepanjang undang-undang tidak mengatur sebaliknya ${ }^{13}$. Kewenangan ini juga diberikan kepada Majelis BPSK, sebagaimana BPSK merupakan penjelmaan dari pengadilan adat di Indonesia $^{14}$. BPSK merupakan lembaga diluar pengadilan yang menyelesaikan sengketa konsumen berdasarkan kekeluargaan dan dengan cara musyawarah dan mufakat yang pada prakteknya menginginkan keduabelah pihak yang bersengketa untuk aktif dalam mencari solusi terbaik bagi kasus yang sedang dihadapi.

Berbeda dengan metode pembuktian dalam KUHPerdata, pembuktian terbalik dalam Pasal 28 UUPK mensyaratkan pembuktian ada atau tidaknya unsur kesalahan pelaku usaha dibebankan pada pelaku usaha itu sendiri. Batasan pembuktian dengan prinsip pembuktian terbalik terletak pada pembuktian kesalahan yang dibebankan pada pelaku usaha $^{15}$. Pada proses penyelesaian sengketa konsumen di BPSK, majelis harus dapat menentukan ada tidaknya hubungan hukum antara konsumen dengan pelaku usaha dan ada tidaknya kerugian konsumen berdasarkan bukti-bukti yang dilampirkan saat mengajukan gugatan ${ }^{16}$. Jika ternyata BPSK melihat bahwa kerugian memang telah diderita oleh konsumen akibat mengkonsumsi dan/atau memanfaatkan barang dan/atau jasa dari pelaku usaha, maka pada saat itu pelaku usaha dianggap melakukan kesalahan, sehingga patutlah kemudian dibuktikan ada tidaknya

\footnotetext{
${ }^{13}$ Sudikno Mertokusumo, Op.Cit, hlm. 141-143

${ }^{14}$ Wawancara dengan Bapak Aman Sinaga, Wakil Ketua BPSK Provinsi DKI Jakarta, tanggal 11 Juni 2015.
}

kesalahan tersebut.

Pasal 28 UUPK berlaku bagi semua pasal yang didalilkan yang memerlukan pembuktian unsur kesalahan pelaku usaha. Permasalahan kemudian timbul ketika UUPK dan peraturan pelaksananya hanya mengatur beban pembuktian bagi pelaku usaha saja, namun tidak menentukan halhal apa saja yang perlu dibuktikan oleh konsumen. Pasal 28 UUPK jo. 22 Kepmenperindag No. 350/MPP/Kep/12/2001 hanya mengatur mengenai beban pembuktian atas unsur kesalahan yang dibebankan pada pelaku usaha.

Dalam literatur ${ }^{17}$, disebutkan bahwa konsumen dibebankan pembuktian atas kerugian yang dialaminya, namun di dalam UUPK dan peraturan pelaksananya hal ini tidak secara jelas dan tegas dinyatakan untuk dibuktikan di hadapan persidangan BPSK. Pembuktian atas kerugian ini sebenarnya telah dilakukan saat konsumen mengajukan gugatan ke BPSK, yaitu dengan memenuhi syarat-syarat pengajuan gugatan yang salah satunya mengharuskan adanya bukti-bukti yang menunjukkan kerugian konsumen, berupa: barang atau jasa yang diadukan, bon, faktur, kuitansi, dan dokumen bukti lain sebagaimana diatur dalam Pasal 16 Kepmenperindag No. 350/MPP/Kep/12/2001. Bukti-bukti ini dijadikan alat oleh Majelis BPSK untuk menyatakan bahwa memang telah terjadi kerugian yang dialami konsumen akibat penggunaan atau pemanfaatan barang dan/atau jasa dari pelaku usaha, namun kewajiban konsumen untuk membuktikan kerugiannya tidak ditegaskan di dalam

15 Wawancara dengan Bapak Johannes Sitepu, Wakil Ketua BPSK Kota Bandung, 08 Juni 2015 ${ }^{16}$ Ibid.

${ }^{17}$ Susanti Adi Nugroho, Op. Cit., hlm. 185 
UUPK dan peraturan pelaksananya sehingga dirasa kurang menjelaskan pembagian beban pembuktian bagi keduabelah pihak.

Pada prakteknya, berdasarkan wawancara yang dilakukan dengan Wakil Ketua BPSK Kota Bandung dan Wakil Ketua BPSK Provinsi DKI Jakarta, pelaksanaan pembuktian di BPSK berpedoman pada asas umum pembuktian serta dengan dengan tetap memperhatikan prinsip pembuktian terbalik serta pengecualian-pengecualian yang diatur dalam UUPK. Pengambilan keputusan juga sangat bergantung pada masing-masing sengketa yang sedang dihadapi. Sebagaimana disebutkan oleh Adrian Sutedi, bahwa pembuktian terbalik membutuhkan pertimbangan yang sangat kasuistis, sebab hakim memiliki kewenangan dan dapat menggunakan kebijaksanaannya untuk menentukan siapa yang berkewajiban melakukan pembuktian ${ }^{18}$. Dalam bukunya, Adrian Sutedi menyatakan bahwa pembagian beban pembuktian dalam prinsip pembuktian terbalik bergantung pada 2 (faktor), yaitu:

a. berdasarkan pertimbangan praktis dan pertimbangan hakim yang berdasarkan keadilan dan kepatutan, dan

b. berdasarkan prinsip-prinsip tanggung gugat yang telah diatur di dalam UUPK.

Berdasarkan asas umum pembuktian pada Pasal 1865 KUHPerdata / 163 HIR, baik penggugat maupun tergugat diberikan hak yang sama untuk membuktikan dalil- dalil yang diajukannya. Berdasarkan pasal ini pula Majelis BPSK dapat membebankan pembuktian kepada salah satu pihak. BPSK juga dapat memerintahkan salah satu pihak untuk membawa bukti-bukti ke persidangan jika Majelis merasa bahwa bukti yang ada belum memenuhi Pasal 21 Kepmenperindag No. 350 / MPP / Kep / 12 / 2001. Ada pun alat bukti berdasarkan Pasal 21 Kepmenperindag No. 350 / MPP / Kep / 12 / 2001 adalah sebagai berikut:
a. barang dan/atau jasa;
b. keterangan para pihak yang bersengketa;
c. keterangan saksi dan/atau saksi ahli;
d. surat dan/atau dokumen;
e. bukti-bukti lain yang mendukung

Penelitian pada BPSK Kota Bandung dan BPSK Provinsi DKI Jakarta menunjukkan bahwa Majelis BPSK dalam proses penyelesaian sengketa konsumen, berwenang dan memiliki hak untuk memerintahkan salah satu pihak melakukan pembuktian jika dirasa perlu berdasarkan ketentuan Pasal 1865 KUHPerdata / 163 HIR. Majelis membebankan pembuktian pada salah satu pihak sesuai dengan keadaan, kemampuan dan kebutuhan pada masing-masing kasus guna mencapai hasil akhir yang memuaskan bagi para pihak (win win solution).

Selain prinsip pembuktian terbalik dalam Pasal 28 UUPK, ketentuan yang juga perlu dipertimbangkan dalam pembuktian adalah Pasal 19 ayat (5) UUPK dan Pasal 27 UUPK. Disebutkan dalam Pasal 19 ayat

18 Adrian Sutedi, Tanggungjawab Produk Dalam Hukum Perlindungan Konsumen, Bogor: Ghalia Indonesia, 2008, hlm. 136 
(5) UUPK bahwa jika kesalahan ada pada pihak konsumen, maka pelaku usaha dibebaskan dari tanggungjawabnya untuk mengganti kerugian yang dituntut konsumen. Pasal ini memberikan peluang bagi pelaku usaha untuk membuktikan bahwa kesalahan ada pada pihak konsumen ${ }^{19}$. Selain itu, pelaku usaha yang memproduksi barang dibebaskan dari tanggungjawab atas kerugian yang diderita konsumen jika Pasal 27 UUPK terpenuhi. Pasal ini memberikan pembebasan bagi pelaku usaha yang memproduksi barang untuk mengganti kerugian jika barang yang dikonsumsi konsumen terbukti seharusnya tidak diedarkan, terdapat cacat yang timbul di kemudian hari dan akibat ditaatinya kualifikasi barang dan lewatnya jangka waktu penuntutan, yaitu 4 (empat) tahun sejak barang dibeli atau lewatnya jangka waktu yang diperjanjikan.

Berdasarkan ketentuan-ketentuan tersebut, dapat dilihat bahwa pelaku usaha tidak hanya dapat membuktikan unsur kesalahannya saja, namun juga dapat membuktikan hal-hal sebagaimana telah disebutkan dalam KUHPerdata dan UUPK agar dapat dibebaskan dari tanggungjawab mengganti kerugian yang dialami konsumen.

Dalam kasus Ludmilla Arif melawan PT NMI, konsumen dimenangkan oleh BPSK dengan memutuskan bahwa PT NMI melanggar Pasal 9 ayat (1) huruf k dan Pasal 10 huruf c UUPK. Pelaku usaha sebenarnya sudah dapat membuktikan ketidakbersalahannya dengan mengadakan test drive dan pengecekan terhadap mobil

19 Lihat Putusan Mahkamah Agung No. 769 K/Pdt.Sus/2011 tanggal 27 Februari 2012 dalam Kasus Muhajidin Taher melawan PT. Bank Mandiri (Persero) Tbk. Pada putusan tersebut Mahkamah Agung membenarkan bahwa kerugian yang dialami konsumen oleh pihak PT NMI. Namun, menurut majelis, pembuktian yang demikian kurang menguatkan dalil PT NMI karena dilakukan oleh pihaknya sendiri. Majelis BPSK kemudian meminta pelaku usaha untuk melakukan pengecekan mobil yang dilakukan pihak ketiga diluar para pihak, namun PT NMI tidak dapat memenuhinya.

Sementara itu, konsumen dalam gugatannya di BPSK hanya mengajukan bukti berupa iklan dan brosur yang menunjukkan bahwa mobil yang dibelinya tidak seirit pemberitaan yang ada, padahal bukti perolehan berupa bon, faktur, kwitansi dan dokumen bukti lain sebagaimana diatur dalam Pasal 16 huruf d Kepmenperindag No. 350 / MPP / Kep / 12 / 2001 sangat dibutuhkan untuk membuktikan kerugian konsumen. Pemberitaan tersebut menjadi pertimbangan Majelis BPSK untuk memutus sengketa. Dalam proses pembuktian di BPSK konsumen tidak mampu mengajukan bukti berupa bon, faktur dan alat bukti lain yang menunjukkan bahwa ia dirugikan dengan pemakaian mobil Nissan March yang dibelinya dari pelaku usaha, padahal buktibukti tersebut sudah seharusnya dilampirkan pada saat pengajuan gugatan ke BPSK. Dalam hal ini konsumen memanfaatkan barang yang dibelinya hanya berdasarkan pada informasi dari pemberitaan saja sebagaimana iklan merupakan media pengenalan produk dan sekaligus untuk menarik minat beli konsumen ${ }^{20}$.

konsumen adalah karena kesalahan konsumen sendiri.

${ }^{20}$ Bambang Eko Turisno, "Perlindungan Konsumen Dalam Iklan Obat", Jurnal Masalah-Masalah Hukum, Volume 40, Nomor 4, 2011, hlm. 21 
Dalam kasus ini seharusnya majelis dengan kewenangannya dapat meminta bukti-bukti lain yang menguatkan dalil konsumen yang menyatakan bahwa ia dirugikan dengan pemakaian mobil Nissan March yang dibelinya agar hak yang didalilkan oleh konsumen dapat terbukti secara jelas di hadapan sidang arbitrase BPSK.

\section{Implikasi Yuridis Putusan BPSK yang Diputuskan Tidak Sesuai dengan Prinsip Pembuktian Terbalik}

BPSK merupakan lembaga yang bertindak sebagai pengadilan kuasi dalam penyelesaian sengketa konsumen ${ }^{21}$. Dikatakan demikian karena BPSK berwenang memeriksa dan memutus sengketa konsumen seolah-olah sebagai sebuah pengadilan, yaitu dengan membentuk Majelis sebagai sebuah panitia ad-hoc yang memeriksa dan memutus perkara dengan pembuktian yang sederhana $^{22}$.

BPSK pada dasarnya merupakan penjelmaan dari pengadilan adat yang menyelesaikan sengketa dengan cara kekeluargaan melalui musyawarah dan mufakat $^{23}$. Adapun tugas dan wewenang BPSK diatur dalam Pasal 3 Kepmenperindag No. 350 / MPP / Kep / 12 / 2001 jo. Pasal 52 UUPK, yaitu:

a. melaksanakan penanganan dan penyelesaian sengketa konsumen dengan cara konsiliasi, mediasi atau arbitrase berdasarkan pilihan dan persetujuan para pihak yang bersengketa dan bukan merupakan proses penyelesaian sengketa yang berjenjang;

b. memberikan konsultasi

perlindungan konsumen terhadap hal-hal yang berhubungan dengan perlindungan konsumen. Konsultasi dalam Pasal 8 Kepmenperindag No. 350 / MPP / Kep / 12 / 2001 dapat berupa konsultasi tentang pelaksanaan hak dan kewajiban konsumen untuk menuntut ganti rugi sehubungan dengan penggunaan atau pemanfaatan barang dan/atau jasa yang merugikan konsumen; konsultasi tentang upaya untuk memperoleh pembelaan dalam penyelesaian sengketa konsumen; konsultasi tentang pelaksanaan hak dan kewajiban pelaku usaha yang berkaitan dengan perlindungan konsumen; konsultasi tentang bentuk dan tata cara penyelesaian sengketa konsumen di BPSK; konsultasi tentang pelaksanaan perundang-undangan yang berkaitan dengan perlindungan konsumen; dan hal-hal lain yang berhubungan dengan perlindungan konsumen.

c. melakukan pengawasan terhadap pencantuman klausula baku, dengan atau tanpa pengaduan dari konsumen. Hasil pengawasan yang membuktikan adanya pelanggaran diberitahukan secara tertulis sebanyak 3 (tiga) kali berturut-turut kepada pelaku usaha sebagai peringatan dari BPSK. Peringatan yang tidak diindahkan oleh pelaku

\footnotetext{
${ }^{21}$ Janus Sidabalok, Op. Cit., hlm. 184

${ }^{22}$ Wawancara dengan Bapak Aman Sinaga, Wakil Ketua BPSK Provinsi DKI Jakarta, 11 Juni 2015.
} 
usaha akan dilaporkan oleh BPSK kepada Penyidik Pegawai Negeri Sipil yang berwenang untuk dilakukan penyidikan dan penuntutan;

d. melaporkan kepada penyidik umum apabila terjadi pelanggaran ketentuan UUPK;

e. menerima pengaduan baik tertulis maupun tidak tertulis dari konsumen tentang terjadinya pelanggaran terhadap perlindungan konsumen;

f. melakukan penelitian dan pemeriksaan terhadap bukti-bukti yang diajukan konsumen dan pelaku usaha, konsumen, pelaku usaha dan saksi-saksi dalam sengketa perlindungan konsumen;

g. memanggil pelaku usaha yang diduga telah melakukan pelanggaran terhadap perlindungan konsumen;

h. memanggil dan menghadirkan saksi, saksi ahli dan/atau setiap orang yang dianggap mengetahui pelanggaran terhadap UUPK;

i. meminta bantuan penyidik untuk menghadirkan pelaku usaha, saksi, saksi ahli, atau setiap orang sebagaimana dimaksud pada huruf $\mathrm{g}$ dan huruf $\mathrm{h}$, yang tidak bersedia memenuhi panggilan BPSK;

j. mendapatkan, meneliti dan/atau menilai surat, dokumen, atau alat bukti lain guna penyelidikan dan/atau pemeriksaan untuk mengetahui adanya pelanggaran terhadap UUPK;

k. memutuskan dan menetapkan ada atau tidak adanya kerugian konsumen akibat mengkonsumsi barang dan/atau jasa dengan penggantian berupa pengembalian uang, penggantian barang dan atau jasa yang senilai atau perawatan kesehatan dan atau pemberian santunan;

1. memberitahukan dan menyampaikan putusan kepada pelaku usaha yang melakukan pelanggaran terhadap perlindungan konsumen secara tertulis;

m. menjatuhkan sanksi administratif kepada pelaku usaha yang melanggar ketentuan UUPK berupa penetapan ganti rugi sebesar Rp. 200.000.000,- (dua ratus juta rupiah) sesuai dengan ketentuan UUPK.

Alternatif penyelesaian sengketa konsumen dengan cara mediasi, konsiliasi atau arbitrase yang menjadi wewenang BPSK dilakukan dengan melibatkan pihak ketiga yang netral dan tidak memihak, yaitu Majelis BPSK yang akan berperan sebagai mediator, konsiliator dan arbiter. Penyelesaian sengketa dengan cara konsiliasi dan mediasi memberikan kewenangan sepenuhnya kepada para pihak atas proses penyelesaian sengketa, baik mengenai bentuk maupun jumlah ganti kerugiannya. Hasil musyawarah yang menjadi kesepakatan dibuat dalam bentuk perjanjian tertulis yang ditandatangani oleh para pihak yang bersengketa. Selanjutnya perjanjian diserahkan kepada Majelis BPSK untuk dikuatkan dalam keputusan BPSK yang mengikat keduabelah pihak tanpa memuat sanksi administratif. Putusan BPSK tersebut hanya megukuhkan isi perjanjian perdamaian yang sebelumnya telah disetujui dan ditandatangani oleh para 
pihak yang bersengketa. Sementara itu, penyelesaian sengketa dengan cara arbitrase memberikan wewenang pada BPSK untuk memeriksa dan memutus sengketa konsumen.

Suatu sidang penyelesaian sengketa konsumen melalui BPSK tidak dapat dilaksanakan jika belum ditentukan metode penyelesaiannya ${ }^{24}$. Prasidang merupakan suatu proses untuk mencari metode penyelesaian sengketa tersebut. Sebelum sidang hari pertama, BPSK menyediakan forum untuk mempertemukan pelaku usaha dan konsumen guna memilih metode penyelesaian yang akan ditempuh untuk menyelesaikan sengketa yang timbul, apakah arbitrase, mediasi atau konsiliasi. Tahap ini tidak diatur dalam peraturan perundang-undangan yang mengatur mengenai perlindungan konsumen, namun berdasarkan pasal 43 Kepmenperindag No. 350/MPP/Kep/12/2001, tahap prasidang diatur oleh Ketua BPSK ${ }^{25}$.

Prasidang dilakukan dengan cara memanggil pelaku usaha dan konsumen untuk hadir di BPSK. BPSK menugaskan 1 (satu) orang Anggota BPSK untuk memimpin prasidang dan dibantu oleh 1 (satu) orang Sekretariat BPSK. Pada kesempatan tersebut akan dijelaskan maksud dilaksanakannya pertemuan, alternatif penyelesaian sengketa yang secara sukarela dapat dipilih para pihak dan harus dicapai kesepakatan untuk menggunakan salah satu dari alternatif penyelesaian sengketa yang ada. Jika salah satu metode penyelesaian sengketa konsumen telah dipilih berdasarkan kesepakatan para pihak, maka BPSK akan

\footnotetext{
24 Wawancara dengan Bapak Johannes Sitepu, Wakil Ketua BPSK Kota Bandung, 08 Juni 2015. ${ }^{25}$ Ibid.
}

mengeluarkan berita acara pemilihan metode penyelesaian sengketa konsumen. Hal ini sesuai dengan Pasal 3 Kepmenperindag No. 350 / MPP / Kep / 12 / 2001 jo. Pasal 52 UUPK yang menyatakan bahwa BPSK berwenang untuk melaksanakan penanganan dan penyelesaian sengketa konsumen dengan cara konsiliasi, mediasi atau arbitrase berdasarkan pilihan dan persetujuan para pihak yang bersengketa dan bukan merupakan proses penyelesaian sengketa yang berjenjang.

Setelah disepakati mengenai cara penyelesaian sengketa, dibentuklah majelis paling sedikit berjumlah 3 (tiga) orang yang mewakili unsur pemerintah yang akan menjadi Ketua Majelis, unsur konsumen dan unsur pelaku usaha yang salah satu anggotanya wajib berpendidikan dan berpengetahuan di bidang hukum. Majelis BPSK yang akan menyelesaikan sengketa dengan cara konsiliasi dan mediasi akan ditentukan dan ditetapkan personilnya oleh BPSK. Hal ini berbeda dengan majelis pada metode arbitrase. Kewenangan utuk memilih dan menentukan siapa yang menjadi Majelis adalah para pihak yang bersengketa ${ }^{26}$.

Pada persidangan pertama ketua majelis wajib mendamaikan keduabelah pihak yang bersengketa. Proses pendamaian konsumen dan pelaku usaha di BPSK Kota Bandung selalu diusahakan setiap saat karena tujuan akhir dari penyelesaian sengketa konsumen di BPSK adalah win-win solution bagi para pihak. Jika perdamaian tercapai, majelis wajib membuat putusan dalam bentuk penetapan

\footnotetext{
${ }^{26}$ Buku Pedoman Operasional ke-2 (dua) Badan Penyelesaian Snegketa Konsumen Provinsi DKI Jakarta, hlm. 22
} 
perdamaian. Jika tidak tercapai perdamaian, maka persidangan dimulai dengan membacakan isi gugatan konsumen dan surat jawaban pelaku usaha. Ketua majelis memberikan kesempatan yang sama kepada konsumen dan pelaku usaha yang bersengketa untuk menjelaskan halhal yang dipersengketakan. Sebelum pelaku usaha memberikan jawabannya, konsumen dapat mencabut gugatannya dengan membuat surat pernyataan. Jika demikian, majelis wajib mengumumkan bahwa gugatan dicabut.

Selama proses penyelesaian sengketa alat-alat bukti yang mendukung dapat diajukan kepada majelis. Proses penyelesaian sengketa konsumen oleh BPSK membebankan pembuktian ada pada pelaku usaha, namun konsumen juga harus mengajukan bukti-bukti untuk membuktikan bahwa ia dirugikan akibat pemakaian produk dan atau jasa dari pelaku usaha. Selain hal tersebut, Pasal 1865 KUHPerdata/163 HIR memberikan kesempatan bagi para pihak yang berhak untuk membuktikan hal-hal yang dianggap perlu. Penerapan pasal ini terlihat ketika Majelis BPSK membebankan salah satu pihak untuk membawa bukti ke persidangan guna membuktikan kebenaran dalil yang diajukan pihak yang bersangkutan. Alat bukti dalam penyelesaian sengketa konsumen menurut Pasal 21 angka 5 Kepmenperindag No. 350/MPP/Kep/12/2001 memungkinkan bukti-bukti lain selain yang telah ditentukan secara limitatif. Bukti-bukti lain ini dapat berupa apa saja yang mendukung pembuktian dalil-dalil yang diajukan para pihak.

27 Wawancara dengan Bapak Johannes Sitepu, Wakil Ketua BPSK Kota Bandung, 08 Juni 2015.
Majelis wajib menyelesaikan sengketa konsumen paling lambat 21(dua puluh satu) hari kerja terhitung sejak gugatan diterima oleh BPSK. Pada prakteknya di BPSK Provinsi DKI Jakarta, perhitungan 21 (dua puluh satu) hari ini ditetapkan sejak disepakatinya metode penyelesaian sengketa konsumen pada saat prasidang. Putusan majelis didasarkan atas musyawarah untuk mencapai mufakat atau dengan suara terbanyak jika mufakat tidak tercapai.

Berdasarkan Pasal 42 Kepmenperindag No. 350/MPP/Kep/12/2001 putusan yang dikeluarkan oleh BPSK adalah final dan mengikat, sehingga memiliki kekuatan hukum yang sama bagi para pihak yang bersengketa untuk dilaksanakan. Dalam mengambil suatu putusan Majelis BPSK bertindak independen. Independen berarti Majelis BPSK tidak tergantung dan tidak dapat diintervensi oleh pihak lain dalam menilai dan mengambil suatu putusan. Kemandirian ini dilakukan agar putusan tersebut dapat diterima sebagai putusan BSPK yang mengikat dan memberikan keadilan bagi para pihak yang bersengketa $^{27}$. Putusan BPSK tersebut tetaplah dipandang sebagai suatu putusan yang mengikat bagi para pihak, walaupun misalnya putusan tersebut diambil tidak sesuai dengan ketentuan pembuktian yang telah diatur dalam UUPK, sebab pada dasarnya putusan BPSK merupakan hasil musyawarah dan mufakat dari para pihak dan merupakan putusan yang diambil oleh serta dilakukan sepenuhnya secara independen oleh Majelis.

Terdapat 2 (dua) sikap yang dapat diambil baik oleh konsumen maupun oleh 
pelaku usaha untuk menanggapi putusan BPSK. Sikap yang pertama adalah menerima putusan dengan cara melaksanakan perintah putusan yang dimaksud. Suatu putusan BPSK dapat berupa perintah untuk mengganti kerugian dan/atau berupa sanksi administratif yang harus diganti oleh pihak yang kalah senilai paling banyak Rp. 200.000.000,- (dua ratus juta rupiah). Pihak yang menerima putusan wajib melaksanakan putusan tersebut paling lambat 7 (tujuh) hari kerja terhitung sejak menyatakan menerima putusan BPSK.

Pada dasarnya pelaku usaha yang dikalahkan lalu mengganti kerugian yang diderita konsumen, maupun konsumen yang dikalahkan namun tidak melakukan upaya hukum keberatan, adalah para pihak yang secara tidak langsung menyatakan menerima suatu putusan BPSK, terlepas putusan tersebut diambil dengan cara yang benar maupun tidak. Ketika putusan BPSK ini diterima oleh para pihak, dan konsumen maupun pelaku usaha tidak mengajukan upaya hukum hingga batas waktu yang telah ditentukan UUPK, maka dengan sendirinya putusan BPSK dianggap telah berkekuatan hukum tetap. Hal ini sesuai dengan ketentuan Pasal 56 ayat (3) UUPK.

Sikap lain yang dapat dilakukan para pihak selain menerima putusan BPSK adalah dengan cara menolak putusan tersebut, misalnya karena telah terjadi ketidaksesuaian cara pengambilan putusan yang dilakukan oleh Majelis BPSK. Jika salah satu pihak merasa dirugikan akibat putusan yang dijatuhkan, maka pihak tersebut dapat mengajukan pembatalan

28 Gredly Laurens Rangka, "Peran Badan Penyelesaian Sengketa Konsumen Menurut Undang-Undang Nomor 8 Tahun 1999”, Jurnal putusan. Pembatalan putusan melalui upaya hukum keberatan hanya dapat dilakukan terhadap putusan arbitrase BPSK saja.

Apabila memang telah terjadi pelanggaran terhadap ketentuan mengenai tata cara penyelesaian sengketa konsumen di BPSK sehinga salah satu pihak merasa dirugikan atas putusan arbitrase BPSK, maka pihak tersebut dapat mengajukan upaya hukum berupa pengajuan keberatan ke pengadilan negeri dimana konsumen berkedudukan. Pasal 3 Perma No. 1 Tahun 2006 jo. Pasal 56 ayat (2) UUPK menyebutkan bahwa keberatan terhadap putusan BPSK dapat diajukan baik oleh pelaku usaha dan/atau konsumen kepada pengadilan negeri di tempat kedudukan hukum konsumen tersebut. Hal ini merupakan konsekuensi dari penerapan sistem peradilan di Indonesia yang memandang bahwa putusan majelis BPSK bersifat nonlitigasi, sehingga apabila ada pihak yang keberatan atas putusan BPSK tersebut, maka pihak tersebut dapat mengajukan kepada pengadilan negeri ${ }^{28}$.

Alasan-alasan yang dapat dijadikan dasar untuk diajukannya keberatan ke pengadilan negeri mengikuti ketentuan persyaratan pembatalan putusan arbitrase sebagaimana diatur dalam Pasal 70 UU No. 30 Tahun 1999 Tentang Arbitrase Dan Alternatif Penyelesaian Sengketa, yaitu surat yang diajukan dalam pemeriksaan setelah putusan dijatuhkan diakui palsu, setelah putusan arbitrase BPSK diambil ditemukan dokumen yang bersifat menentukan yang disembunyikan pihak lawan, dan putusan diambil dari hasil tipu

Ilmu Hukum Legal Opinion, Volume 2, Edisi I, 2014, hlm. 5 
muslihat yang dilakukan salah satu pihak.

Dalam hal pengajuan keberatan atas putusan arbitrase BPSK, terdapat ketentuan lain yang memberikan kesempatan lebih bagi pada pihak yang ingin mengajukannya. Pasal 6 ayat (5) Perma No. 1 Tahun 2006 menyebutkan bahwa pihak yang keberatan dapat mengajukan gugatannya tersebut dengan alasan lain di luar alasan-alasan yang sudah disebutkan dalam Pasal 6 ayat (3) peraturan yang sama. Alasan ini dapat berupa alasan apa saja yang mendasari pihak pengaju keberatan mengajukan gugatan pembatalan putusan BPSK ke pengadilan negeri, termasuk pula alasan yang menyatakan bahwa telah terjadi kesalahan pertimbangan Majelis BPSK yang mendasarkan putusan pada pembuktian yang tidak sesuai dengan prinsip pembuktian terbalik sebagaimana diatur dalam Pasal 28 UUPK $^{29}$. Ketentuan tersebut menunjukkan bahwa implikasi yuridis suatu putusan BPSK yang diputuskan tanpa memperhatikan prinsip pembuktian terbalik sebagaimana diatur dalam Pasal 28 UUPK adalah pembatalan putusan melalui pengajuan keberatan ke pengadilan negeri.

Berdasarkan Pasal 6 Ayat (5) Perma No. 1 Tahun 2006, majelis hakim diberikan wewenang untuk mengadili sengketa konsumen yang diajukan atas dasar alasan lain diluar alasan-alasan yang telah ditentukan. Dalam mengadili sendiri, majelis hakim harus tetap memperhatikan ganti kerugian sebagaimana diatur dalam Pasal 19 ayat (2) UUPK. Selain itu, Majelis Hakim Pengadilan Negeri harus mampu menyelesaikan dan memutus perkara keberatan atas putusan BPSK dalam kurun waktu 21 (dua puluh satu) hari sejak sidang pertama dilakukan. Jika terhadap putusan pengadilan negeri masih ada pihak yang tidak terima, maka pihak tersebut dapat mengajukan kasasi ke Mahkamah Agung dalam waktu paling lama 14 (empat belas) hari setelah menerima putusan tersebut.

Permasalahan timbul ketika suatu putusan BPSK yang sudah berkekuatan hukum tetap (inkracht) disadari kemudian oleh salah satu pihak sebagai putusan yang proses pembuktiannya tidak sesuai dengan ketentuan UUPK. UUPK tidak mengenal upaya hukum peninjauan kembali. Upaya peninjauan kembali dirasakan menyalahi semangat perlindungan konsumen dalam proses penyelesaikan sengketa yang mengharapkan efisiensi waktu. Proses peninjauan kembali memakan waktu yang panjang dan proses yang rumit. Sementara itu, efisiensi waktu sengaja diupayakan agar menjadikan proses penyelesaian sengketa di BPSK, upaya keberatan di pengadilan negeri dan Kasasi di Mahkamah Agung lebih cepat dari pada proses pengadilan pada umumnya. Hal ini merupakan salah satu upaya perlindungan konsumen dalam proses penyelesaian sengketa konsumen di BPSK yang diharapkan dapat dilaksanakan dengan singkat, jelas, mudah, sederhana dan ringan.

Alasan lain yang menjadikan tidak dapat dilakukannya peninjauan kembali atas putusan BPSK adalah bahwa upaya peninjauan dimungkinkan hanya terhadap putusan pengadilan yang sudah inkracht.

Hal ini sesuai dengan Pasal 34 UndangUndang Nomor 14 Tahun 1985 tentang Mahkamah Agung sebagaimana telah dua kali diubah dengan Undang-Undang Nomor 5 Tahun 2004 dan dengan Undang-

${ }^{29}$ Susanti Adi Nugroho, Op. Cit., hlm. 185 
Undang Nomor 3 Tahun 2009 Tentang Perubahan Kedua Atas Undang- Undang Nomor 14 Tahun 1985 tentang Mahkamah Agung yang menyebutkan bahwa Mahkamah Agung memeriksa dan memutus permohonan peninjauan kembali pada tingkat pertama dan terakhir atas putusan pengadilan yang telah memperoleh kekuatan hukum tetap berdasarkan alasanalasan yang diatur dalam Bab IV Bagian Keempat undang-undang tersebut. Sementara itu, menurut Pasal 49 UUPK, BPSK merupakan badan penyelesaian sengketa konsumen diluar pengadilan. Ketentuan ini menunjukkan bahwa BPSK bukanlah suatu pengadilan.

Pada prakteknya, pihak yang tidak menerima putusan atas sengketa konsumen hanya dapat mengajukan permohonan peninjauan kembali atas putusan Mahkamah Agung dan atau Putusan Pengadilan Negeri, bukan terhadap putusan $\mathrm{BPSK}^{30}$. Adapun permohonan peninjauan kembali dapat dilakukan atas putusan pengadilan yang telah memperoleh kekuatan hukum tetap.

\section{PENUTUP}

Berdasarkan pembahasan terhadap masalah dalam penulisan ini, maka dapat ditarik kesimpulan bahwa pembagian beban pembuktian dalam proses penyelesaian sengketa konsumen di BPSK dikaitkan dengan prinsip pembuktian terbalik dalam UUPK harus dilaksanakan dengan tetap berpedoman pada asas umum pembuktian sebagaimana diatur dalam Pasal 1865 KUHPerdata/163 HIR serta Pasal 19 ayat (5) dan Pasal 27 UUPK. Pasal 1865

30 Lihat Putusan Mahkamah Agung No. 769 K/Pdt.Sus/2011 tanggal 27 Februari 2012 dalam Kasus Muhajidin Taher melawan PT. Bank Mandiri (Persero) Tbk. Konsumen mengajukan permohonan
KUHPerdata/163 HIR memberikan wewenang kepada majelis untuk membebankan pembuktian bagi para pihak dengan melihat kasus per kasus, sedangkan Pasal 19 ayat (5) dan Pasal 27 UUPK memberikan beberapa pengecualian dalam hal pembuktian di BPSK. Walaupun demikian, pada praktiknya UUPK dirasa kurang jelas dalam mengatur pembagian pembuktian yang dilakukan pelaku usaha maupun konsumen.

Implikasi yuridis suatu putusan BPSK yang diputuskan tidak sesuai dengan prinsip pembuktian terbalik sebagaimana diatur dalam UUPK adalah penolakan putusan dengan melakukan pembatalan putusan melalui pengajuan keberatan ke Pengadilan Negeri. Putusan pengadilan negeri yang dirasakan belum memberikan keadilan dapat diajukan kasasi ke Mahkamah Agung oleh pihak yang tidak menerimanya. Sementara itu, upaya hukum luar biasa dengan peninjauan kembali tidak dapat dilakukan terhadap Putusan BPSK. UUPK tidak mengenal peninjauan kembali karena menyalahi maksud singkat, jelas, mudah, sederhana dan ringan dalam penyelesaian sengketa konsumen. Alasan lainnya adalah bahwa peninjauan kembali hanya diajukan terhadap putusan pengadilan, sementara itu BPSK merupakan badan penyelesaian sengketa diluar pengadilan.

\section{UCAPAN TERIMAKASIH}

Penulis mengucapkan terimakasih kepada tim pembimbing:

1. Dr. Elisatris Gultom S.H., M.Hum., Dosen Fakultas Hukum Universitas

peninjauan kembali atas putusan Mahkamah Agung dan Putusan Pengadilan Negeri, bukan terhadap putusan BPSK. 
Padjadjaran

2. Deviana Yuanitasari, S.H., M.H., Dosen Fakultas Hukum Universitas Padjadjaran

\section{DAFTAR PUSTAKA}

\section{Buku}

Achmad Ali dan Wiwie Heryani, AsasAsas Hukum Pembuktian Perdata, Jakarta: Kencana, 2012

Adrian Sutedi, Tanggungjawab Produk Dalam Hukum Perlindungan Konsumen, Bogor: Ghalia Indonesia, 2008

Ahmadi Miru \& Sutarman Yodo, Hukum Perlidungan Konsumen, Jakarta: Raja Grafindo Persada, 2004

Gunawan Widjaja dan Ahmad Yani, Hukum Tentang Perlindungan Konsumen, Jakarta: Gramedia Pustaka Utama, 2003.

Janus Sidabalok, Hukum Perlindungan Konsumen Di Indonesia, Bandung: Citra Aditya Bakti, Cetakan Ke III, 2014.

Subekti, Hukum Pembuktian, Jakarta: Pradnya Paramita, 1983.

Sudikno Mertokusumo, Hukum Acara Perdata Indonesia, Yogyakarta: Liberty Yogyakarta, Edisi kedelapan, 2009.

Susanti Adi Nugroho, Proses Penyelesaian Sengketa Konsumen Ditinjau Dari Hukum Acara Serta Kendala dan Implementasinya, Jakarta: Prenada Media Group, 2008.

\section{Jurnal dan Artikel}

Liya Sukma, "Pertanggung Jawaban Produk (Product Liability) Sebagai Salah Satu Alternatif Perlindungan Konsumen”, Dialogia Iuridica,
Volume 7 Nomor 2, 2016

B. Rini Heryanti dan Dewi Tuti Muryati, "Pelaksanaan Tugas Dan Wewenang Badan Penyelesaian Sengketa Konsumen (BPSK) Kota Semarang Dalam Penyelesaian Sengketa Konsumen Berdasarkan UndangUndang No.8 Tahun 1999 Tentang Perlindungan Konsumen", J. Dinamika Sosbud, Volume 13 Nomor 2, 2011

\section{Peraturan Perundang-undangan}

Kitab Undang-Undang Hukum Perdata Undang-Undang Nomor 8 Tahun 1999 Tentang Perlindungan Konsumen

Keputusan Menteri Perindustrian Dan Perdagangan No. 350/MPP/Kep/12/2001 Tentang Pelaksanaan Tugas Dan Wewenang Badan Penyelesaian Sengketa Konsumen

Peraturan Mahkamah Agung Nomor 1 Tahun 2006 tentang Tata Cara Pengajuan Keberatan Terhadap Putusan BPSK

Putusan Mahkamah Agung No. 769 K/Pdt.Sus/2011 tanggal 27 Februari 2012 dalam Kasus Muhajidin Taher melawan PT. Bank Mandiri (Persero) Tbk

Putusan Mahkamah Agung No. 659K/Pdt.Sus/2012 tanggal 26 Maret 2013 dalam Kasus Ludmilla Arif melawan PT Nissan March Indonesia (PT NMI)

\section{Wawancara dan Rujukan Terkait}

Wawancara dengan Bapak Aman Sinaga, Wakil Ketua BPSK Provinsi DKI Jakarta, tanggal 11 Juni 2015.

Wawancara dengan Bapak Johannes 
Dialogia luridica: Jurnal Hukum Bisnis dan Investasi

Volume 9 Nomor 1 November 2017

Sitepu, Wakil Ketua BPSK Kota

Bandung, 08 Juni 2015

Buku Pedoman Operasional ke-2 (dua)

Badan Penyelesaian Sengketa

Konsumen Provinsi DKI Jakarta 